\title{
The Effect of Political Relation on Firm Value at Manufacturing Companies
}

\author{
Luxy Meida Happy Timami ${ }^{1}$, Makaryanawati ${ }^{2 *}$
}

\author{
${ }^{1,2}$ State University of Malang \\ ${ }^{*}$ Correspondence author.Email: makaryanawati.fe@um.ac.id.
}

\begin{abstract}
This research aims to determine the effect of political relation on the firm value at basic chemical manufacturing companies listed on the Indonesia Stock Exchange. The reason for using chemical and basic industry sectors is it has a growth of high stock price. The type of this research is an explanatory quantitative research.

Data collected based on annual reports from 68 manufacturing companies in the chemical industry and basic sectors in Indonesia during the period 2014- 2017. The total sample in this research was 251 companies. Political relations are measured by using Dummy variable and companies' value measured by using Tobins' q. This study used multiple linear regression analysis technique.

The results of this research show that political relations have a positive effect on firm value and also indicate that companies whose have the political relations get facilities access from the government, so it can be used to achieve company goals, which is increasing companies' value. The limitation of this research is the companies' annual report only describe relations from direct political relations. Therefore, indirect relationships such as friendship and family cannot be identified. Suggestions for further research related to political relations on firm value is to replace Dummy variable measurement with ratio data.
\end{abstract}

Keywords: Political Connection, Firm Value, Manufacture

\section{INTRODUCTION}

The main purpose of a firm is to maximize the value of the company. The company's value is company's selling price when a company will be sold (Sugeng, 2015 , p. 9). A high value becomes a longing for every company, because it indicates the success of strategy used by companies in achieving the target which indicate companies' wealth (Hermuningsih, 2013). The higher the stock price, the higher company's value in investors' view (Hermuningsih, 2013).

The company's success is not only seen from the company's influence, but also the influence of an environment. One of the successful environmental factors is a politic (Wulandari \& Prog, 2013). The company who's oriented to political parties' profit will expect a reward (Wulandari \& Raharja, 2013). Rewards given to donors of political parties can be a form of political access, the project access in government or policy that is beneficial to both company and the parties (Faisal, et al., 2018). Political relations can be seen from the management structure or directors as government officials (Wulandari \&
Raharja, 2013). Each individual, either the organizer or management team in a company must have beneficial social connection or relations (Dicko, 2016). Faccio (2006) also explained that political relations provide a significant benefit to companies in terms of ease of access to debt payment, lower income tax payments and possession of substantial market power.

However, practically, political activity does not always go in plan, some cases are often faced by individual such as authority abuse. One of the cases is PT Lapindo Brantas, which received a loan from the government related to the compensation fund for residents of Porong, Sidoarjo, East Java (Kusumawati, 2015). The government provides a loan to PT Lapindo Brantas since the company claimed could not pay the compensation to the affected residents in Sidoarjo due to digging to deep mud. The loan given by the government was IDR 781 billion and must be returned within four years (Kusumawati, 2015). The existence of such cases would be advantageous for the company because of the compensation given by the government 
to lighten the burden debt of society. However, high government debt can lead to financial distress that reducing the value of the company and lead the company out of business or bankrupt (Hermuningsih, 2013).

This research refers to research conducted by Yang, et. al., (2012), Goldman et. al. (2009), faccio (2006), Amorita (2017) and Almuntasir (2016) whose stated that political relation has a positive effect on firm value. The differences to previous studies is in the measurement of the dependent variable used, Tobins' $\mathrm{q}$, research year, and company selected as research object.

Research on political connections have been carried out and show that the political relation has a positive effect on firm value (Yang, et. al., 2012; faccio, 2006; Datta \& Ganguli, 2014; Fisman, 2001; Song, et. Al., 2016; Ang, et. al., 2011 and Chang \& Wong, 2004). Based on some research, political relation has a positive effect on the value of the company because the company which has a strong relationship with politicians and businesspersons results a huge profit (faccio, 2006; Datta \& Ganguli, 2014). Political relation has a positive effect on the value of the company as well as their political relation give a contribution in form of a huge profit to the country (Fisman, 2001), it indicates that companies with political relation is more superior compared to companies that do not have political relations.

H1: Political relation has a positive effect on firm value.

\section{LITERATURE REVIEW}

\subsection{Political Relation}

Political relation can occur if the largest shareholder or corporate executives (CEO, president, vice president or secretary) also has a position as a member of parliament, ministers, president, king or queen, or closely related to the top politicians, state officials or institutions of the state (faccio, 2006). Political relation means the closeness between business owners and the government. Proximity to the government can be used by owners of the company for the benefit of the company. Political relation in the composition of the board of commissioners and board of directors of the company raise many irregularities, including the privilege to obtain loans from government banks, lighter tax, access to government contracts, protection through government regulation (Wulandari, 2018).
Political relation within the company also enables for organizations to gain the access for information from the government. Companies connected politically can access an external bank financing easily, with more favourable terms, which can reduce the incentive to hold cash to fund future investment needs (Kusnadi \& Wei, 2012). Political connections also contributed to a larger percentage of company value (Fisman, 2001).

\subsection{The value of the company}

The company has a long-term goal is to maximize shareholder by maximizing company value (Dewi \& Wirajaya, 2013). The company's value can be calculated through the company's market value (market value ratio). The ratio related to the performance assessment of company stock which has been traded in the capital market. The value of a company created by managing the company performance in order to increase the incomme and reduce the risk (Sugeng, 2017, p. 10). Management should optimally manage the company to produce a high value for the company, so it can prosper the wealth of the owner and welfare to the employees.

\section{RESEARCH METHOD}

Independent variables used in this research are political relation. Political relation in this study is measured by using Dummy Variable, where the score 1 is given to companies that have the political relation and the score 0 is given to the companies a company does not have political relation (Wulandari and Raharja, 2013). Criteria political connections in this study are:

1. Directors or commissioners who have a position as politicians, affiliated with political parties.

2. Directors or commissioners who have a position as a government official.

3. Directors or commissioners who have a position as military officer.

4. Directors or commissioners are former government official or former military officer.

The dependent variable in this research is represented by using Tobin'q ratio, namely the market value of equity plus the book value of preferred shares plus the book value of short-term debt plus the book value of long-term debt minus liquid assets and book value 
divided by total assets (Ang Ding \& Thong, 2011 ). This research also uses a control variable leverage measured by using a ratio of DER, profitability measured by using ROA, size measured by using $\ln$ (total assets) and growth measured by using the difference in current year sales to last year, and then divided with the market value of equity.

The population in this research are all basic manufacturing companies of chemical sectors listed in Indonesia Stock Exchange in 2014 to 2017. This research used a purposive sampling technique to obtain samples. Criteria for the sample in this study are (1). Companies belong to the manufacturing (chemical and basic) listed in Indonesia Stock Exchange (BEI) in 2014 to 2017, (2) Companies that report annual report from 2014-2017. The total sample in this study are 251 companies.

This research used a secondary data. Source of research data obtained from several website, corner of Indonesia Stock Exchange (BEI), Faculty of Economics in University of Malang and web sites related company.

Hypothesis testing is done by multivariate analysis using multiple linear regression as follows:

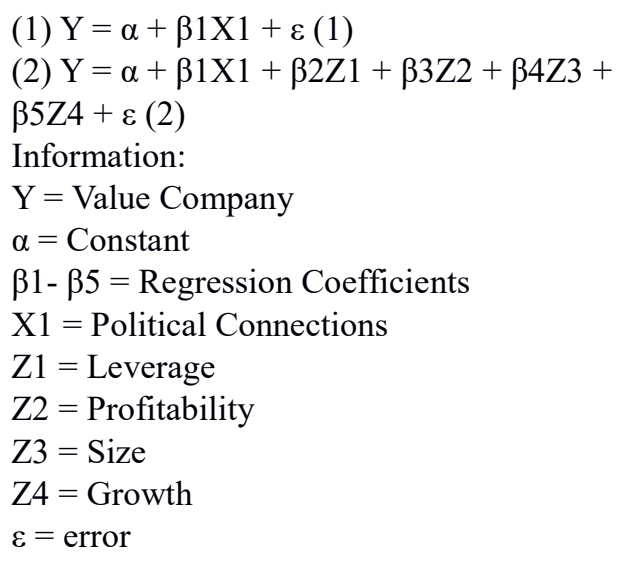

\section{RESULTS AND DISCUSSION}

\subsection{Descriptive Statistics}

Descriptive statistics present data minimum value, maximum, mean and standard deviation of each variable. Description of the research data will be presented in Table 1 below:

Table 1. Descriptive Statistics

\begin{tabular}{llllll}
\hline & N & Minimum & maximum & mean & Std. deviation \\
\hline Z1 Leverage & 251 & .008 & 7742 & 0605 & .737 \\
\hline Z2 Profitability & 251 & -.632 & .460 & 0016 & .086 \\
\hline Z3 Size & 251 & 22758 & 32270 & 28291 & 1,713 \\
\hline Z4 Growth & 251 & -83401 & 33517 & -0278 & 6589 \\
\hline Y Value Company & 251 & -.835 & 9783 & 0949 & 1,560 \\
\hline Valid N (listwise) & 251 & & & &
\end{tabular}

Based on Table 1, leverage has a mean value amount of $60.5 \%$, which means that the company's leverage is in above-average level amount $40 \%$ of the manufacturing industry (Brigham \& Houston, 2001). It shows that more companies use debt to finance assets of the equity capital that the risk of financial distress in the company is quite high and the companies that have high levels of debt creditors will not provide additional funding because it can lead to bankrupt (Brigham \& Houston, 2001). Leverage has a standard deviation of 0.737 , it shows the difference among the company's leverage is low enough.

The mean value of the profitability amount of $1.6 \%$, it indicates that the company's average profit is still relatively low and below the industry average of $9 \%$ (Brigham \& Houston, 2001). This is due to the losses of 70 companies from 251 companies. Standard deviation score amount of 0.086 also indicate the differences in profitability among low companies manufacturing, this may be caused by manufacturing companies that have almost the same type of business that they have similar business risks.

The size of a company is measured by using natural logs that have a mean total asset amount of 28.291 value which indicates that the size of the manufacturing companies is moderate (Japlani, 2015). It shows that a large company's assets could be used to finance the company operational. 
The mean value of -0278 indicates that many manufacturing companies have negative sales growth or declining sales. It means, in the future, the manufacturing company's sales growth will have a lot of losses. The differences in sales growth which is relatively high among companies is 6.589 .

The negative minimum value of the company for current assets INRU is higher than the market value and total liabilities. The mean of the company's value is 0.949 , which pointed to a manufacturing company that is still relatively low. It be caused the value of the company which is under the value of 1 , it means that investors do not give premium to the issuer, indicating the $\mathrm{Q}$ value is less than 1 , which means the company's market price is below the price of the book (Weston \& Copeland, 2010). Standard deviation indicates that the data distribution enterprise value amount of 1.56 , which means the difference value of the company is quite high among companies.

Table 2. Political Connections (X)

\begin{tabular}{lll}
\hline Information & frequency & Percent \\
\hline Political connections & 77 & 30.68 \\
\hline Not Connected Politics & 174 & 69.32 \\
\hline Total & 251 & 100.00 \\
\hline
\end{tabular}

The data show that $30.6 \%$ companies have political relation with the government. By their political connections, companies can give a huge contribution.

\subsection{Correlation Analysis}

Table 3. Correlation Analysis Results

\begin{tabular}{lllllll}
\hline \multicolumn{1}{c}{ variables } & $\mathbf{1}$ & $\mathbf{2}$ & $\mathbf{3}$ & $\mathbf{4}$ & $\mathbf{5}$ \\
\hline 1 & Y Value Company & & & & \\
\hline 2 & X Political Connections & $.403^{* *}$ & & & \\
\hline 3 & Z1 Leverage & $.399^{* *}$ & $.187^{*}$ & & & \\
\hline 4 & Z2 Profitability & -.080 & $.115^{* *}$ & $-.369^{* *}$ & & \\
\hline 5 & Z3 Size & $.361^{* *}$ & $.563^{* *}$ & $.236^{* *}$ & -.070 & \\
\hline 6 & Z4 Growth & -.102 & -.098 & $.187^{*}$ & .061 & -.093 \\
\hline
\end{tabular}

\footnotetext{
* Significant at $p<0: 01$; ** $P<0.05$.
}

The results of correlation analysis shows that political relation gives a positive influence to the company's value amount of 0.01 . Control variable leverage and size company also has a positive correlation with the value of the company. However, variable control profitability and sales growth are not related to the company's value.

Table 4. Regression Testing Result

\section{Hypothesis-Testing}

After the classical assumption data meets the requirements, then the Model I regression is carried out on the table below:

\begin{tabular}{lcl}
\hline & Model I & Model II \\
\hline (Constant) & 0384 & -.705 \\
\hline X Political Connections & $0329^{* * *}$ & $.199^{* *}$ \\
\hline Z1 Leverage & & $.593^{* * *}$ \\
\hline Z2 Profitability & .347 \\
\hline Z3 Size & & .030 \\
\hline Z4 Growth & 0162 & -.197 \\
\hline R2 & & .301 \\
\hline
\end{tabular}


The test results can be interpreted as, when X (political connections) is 0 , then $\mathrm{Y}$ (the value of the company) is in amount of 0,384 . When companies have political relation with the government, then a chance to increase the company's value is in amount of 32 .

Based on the test results, there are differences in constant value $(\alpha)$ of the model equations I and II, from 0,384 becomes -0.705 . It is because company size changes the constant value of the control variable, this change caused by two things. First, because of significant differences in the size of the company with the highest value reached IDR 103 trillion and IDR 7 Billion lowest value. Second, due to the difference in

F-test

F-test of political relation, leverage, profitability, size, and growth of the company shows a significant value value between the value of the companies which have an average value amount of 0.949 with the size of companies which have an average value amount of 28.291. This makes the constant value in the regression equation becomes negative. However, a negative constant value which does not affect the results of the regression equation, because the classical assumption test had been met and the value of the slope $(\beta)$ is worth 0 (Dougherty, 2011). The $\mathrm{R} 2$ value of political connections on the model II amounted to 0.301 , which means $30 \%$ of the variation or variability in the value of the company is described by political relation.

Table 5. Results of Test F

\begin{tabular}{lccccc}
\hline Model & $\begin{array}{c}\text { Sum of } \\
\text { Squares }\end{array}$ & Df & $\begin{array}{c}\text { mean } \\
\text { Square }\end{array}$ & F & Sig. \\
\hline Regression & 5,396 & 5 & 1,079 & 11,170 & $.000 \mathrm{~b}$ \\
\hline residual & 12560 & 130 & .097 & & \\
\hline Total & 17956 & 135 & & & \\
\hline
\end{tabular}

T-test

T-test results in Table 4.6 show that the significance of political relation (variable $\mathrm{X}$ ) to firm (variable $\mathrm{Y}$ ) is
0.009 or $<0.05$, it can be said that political relation effect positively on firm value. Based on this, the hypothesis that political relation has a positive effect on the firm value is received.

Table 6. T-test result

\begin{tabular}{|c|c|c|c|c|c|}
\hline \multirow[t]{2}{*}{ Model } & \multicolumn{2}{|c|}{$\begin{array}{c}\text { Coefficients } \\
\text { unstandardized }\end{array}$} & \multirow{2}{*}{$\begin{array}{c}\begin{array}{c}\text { standardized } \\
\text { Coefficients }\end{array} \\
\text { beta }\end{array}$} & \multirow[t]{2}{*}{$\mathbf{T}$} & \multirow[t]{2}{*}{ Sig. } \\
\hline & B & Std. Error & & & \\
\hline (Constant) & -.705 & .595 & & -1185 & .238 \\
\hline X Political Connections & .199 & .075 & .243 & 2647 & .009 \\
\hline Z1 Leverage & .593 & .138 & .365 & 4,294 & .000 \\
\hline Z2 Profitability & .347 & .648 & .044 & .536 & .593 \\
\hline Z3 Size & .030 & .021 & .128 & 1,416 & .159 \\
\hline Z4 Growth & -.197 & .110 & -.138 & -1793 & .075 \\
\hline
\end{tabular}




\section{Robustness Test}

The following are the results of tests that show the robustness of the correlation analysis, F-test and T-test that has been qualified to classical assumption test

\subsection{Hypothesis}

Table 7. Regression Testing

\begin{tabular}{lcc}
\hline & Model I & Model II \\
\hline (Constant) & 0763 & 2,154 \\
\hline X Political Connections & $0267 * * *$ & $.339 * * *$ \\
\hline Z1 Leverage & & -.024 \\
\hline Z2 Profitability & 1,382 \\
\hline Z3 Size & & $-.061 * *$ \\
\hline Z4 Growth & & -.108 \\
\hline R2 & 0100 & .178 \\
\hline
\end{tabular}

* Significant at $p<0: 01 ; * * P<0.05 ; p$ $<0.001$

Test F

Table 8. Test F Result

\begin{tabular}{lrrrrr}
\hline Model & Sum of Squares & Df & $\begin{array}{c}\text { mean } \\
\text { Square }\end{array}$ & \multicolumn{1}{l}{ F } & \multicolumn{1}{c}{ Sig. } \\
\hline Regression & 3557 & 5 & .711 & 5,100 & $.000 \mathrm{~b}$ \\
\hline residual & 16460 & 118 & .139 & & \\
\hline Total & 20017 & 123 & & & \\
\hline
\end{tabular}

T-test

0.000 or $<0.05$, so it can be said that political relation has a positive effect on firm value.

T-test results in Table 4.13 show that the significance of political relation (variable $\mathrm{X}$ ) to firm (variable $\mathrm{Y}$ ) is 
Table 9. t-Test Results

\begin{tabular}{|c|c|c|c|c|c|}
\hline \multirow[t]{2}{*}{ Model } & \multicolumn{2}{|c|}{$\begin{array}{c}\text { Coefficients } \\
\text { unstandardized }\end{array}$} & \multirow{2}{*}{$\begin{array}{c}\begin{array}{c}\text { standardized } \\
\text { Coefficients }\end{array} \\
\text { beta }\end{array}$} & \multirow[t]{2}{*}{$\mathbf{T}$} & \multirow[t]{2}{*}{ Sig. } \\
\hline & B & Std. Error & & & \\
\hline (Constant) & 2,154 & .519 & & 4,152 & .000 \\
\hline $\begin{array}{l}\text { X Political } \\
\text { Connections }\end{array}$ & .339 & .079 & .402 & 4,291 & .000 \\
\hline Z1 Leverage & -.024 & .210 & -.011 & -.113 & .910 \\
\hline Z2 Profitability & 1,382 & .812 & .164 & 1,702 & .091 \\
\hline Z3 Size & -.061 & .023 & -.257 & -2621 & .010 \\
\hline Z4 Growth & -.018 & .221 & -.007 & -.079 & .937 \\
\hline
\end{tabular}

Based on the control variables were tested showed that the size indicates the significance amount of 0.010 , which means the size effects firm value. The leverage, profitability, and growth control variables show significance above 0.05 , which means that profitability, size, and growth do not affect the firm's value. Leverage and size have different results on the robustness test. This is because the difference in the value of company measurement in using $\mathrm{MB}$ to measure firm value. The measurement conducted by using MB measurement, while the measurement of the company's equity value used Tobins' q, namely debt value and assets. Based on the measurement results, there are differences in the test results of regression, due to the fact that some companies have a company's value amount of -1951.37 , so it affects the differences in the results of hypothesis testing.

\subsection{Influence of Political Relation Against Corporate Values}

The results show that political relation has a positive effect on firm value. These results are consistent with research conducted by Ang, et. al (2011), Almuntasir (2016), Amorita (2017), Chang and Wong (2004), Datta \& Ganguli (2014), Faccio (2006), Fisman (2001), Goldman et. al (2009), Song, et. Al (2016), and Yang, et. Al (2012). These results indicate that the political relations within the company can increase the value of the company.

Companies that have political relation can increase their value by $32 \%$ during the study period. This indicates that their political relation can affect the value of the company. Therefore, the company can improve its political relation with the government in order to enhance shareholder value. These results are confirmed in the robustness test which explain that political relations can enhance shareholder value.
Political relation affect companies' value, because the development of the manufacturing industry is expanding as evidenced by the increasing investment and activities undertaken (Hidayat \& Husaini, 2019). The acceleration of expansion is supported by providing fiscal and licencing facilities (Hidayat \& Husaini, 2019). Based on the description above, political relations will have easy access from the government and licensing facility that can be used to launch operations firms, so as to enhance shareholder value.

\section{CONCLUSIONS}

Based on the results of tests performed, it can be concluded that the political relation has a positive effect on firm value. These results are consistent with previous studies that found a positive effect of political relation on firm value. The results of this study indicate that companies with political relation get an access to the conveniences of the government that can be used to achieve the purpose of the company, namely increasing company's value.

The results of this study can be taken into consideration in taking decision by some parties. For potential investors, to invest in companies with political connections because of their political connections can enhance shareholder value. For companies, management can improve the political connections in the company in order to affect the value of the company. For further research, this research can be a point of comparison for the study of factors that affect the value of the company. 


\section{REFERENCES}

[1] Al-Muntasir., \& Asri, M. (2016). Hubungan koneksi politik dan kinerja perusahaan dengan indeks persepsi korupsi dan corporate governance sebagai variabel [Thesis Master's Published]. Yogyakarta: Gadjah Mada University. Retrieved from http://etd.repository.ugm.ac.id/index.php?mo $\mathrm{d}=$ penelitian_detail\&sub=PenelitianDetail\& act=view\&typ=html\&buku_id=103444\&oby ek id=4.

[2] Amorita, N. N. (2017). Koneksi politik dan nilai perusahaan [Published Thesis]. Surabaya: Airlangga University. Retrieved http://repository.unair.ac.id/60388/.

[3] Ang, J. S., Ding, D. K., \& Thong, T. Y. (July, 2011). Political connection and firm value. China International Conference in Finance. Research Collection Lee Kong Chian School Of Business, Wuhan. Retrieved from https://ink.library.smu.edu.sg/lkcsb research /4439/.

[4] Brigham, E. F., \& Houston, J. F. (2001). Fundamentals of financial management [8th ed], H, Wibowo., \& D, Suharto [eds]. Jakarta: Erlangga.

[5] Chang, E. C., \& Wong, S. M. L. (2004). Political control and performance in China's listed firms. Journal of Comparative Economics, 32(4), 617-636. Doi: 10.1016 / j.jce.2004.08.001.

[6] Datta, D., \& Ganguli, S. K. (2014). Political connection and firm value: An Indian perspective. South Asian Journal of Global Business Research, 3(2), 170-189. Doi: 10.1108/SAJGBR-03-2013-0020.

[7] Dewi, A. S. M., \& Wirajaya, A. (2013). Pengaruh struktur modal, profitabilitas dan ukuran perusahaan pada nilai perusahaan. $E$ Jurnal Akuntansi Universitas Udayana, 4(2), 358-372.

[8] Dicko, S. (2016). The impact of political connections on the performance and solvency of Canadian financial institutions. International Journal of Economics and Finance, $\quad 8(11), \quad 1-11$. doi:10.5539/ijef.v8n11p1.

[9] Dougherty, C. (2011). Introduction to econometrics. Oxford: OUP Oxford.

[10]Faccio, M. (2006). Politically connected firms. The American Economic Review,
96(1), 369-386. Retrieved from http://www.jstor.org/stable/30034371

[11] Faisal, F., Barid, B., \& Mulyanto, D. (2018). Pendanaan partai politik di Indonesia: Mencari pola pendanaan ideal untuk mencegah korupsi. Integritas, 4(1). Doi: 10.32697/integritas.v4i1.248.

[12]Fisman, R. (2001). Estimating the value of political connections. The American Economic Review, 91(4), 1095-1102. Retrieved from https://www.jstor.org/stable/2677829

[13] Goldman, Eitan., Rocholl, J., \& So, J. (2009). Do politically connected boards affect firm value ? The Review of Financial Studies, 22(6), 2331-2360. Retrieved from http://rfs.oxfordjournals.org/.

[14] Hermuningsih, S. (2013). Pengaruh profitabilitas, growth opportunity, struktur modal terhadap nilai perusahaan pada perusahaan public di Indonesia. Buletin Ekonomi Moneter dan Perbankan, 16(2), 1127. Doi: 10.21098/bemp.v16i2.27.

[15] Hidayat, A. (March 14th, 2019). Menperin: Industri manufaktur dinilai masih ekspansif, A, Husaini [ed]. Retrieved from https://industri.kontan.co.id/news/menperinindustri-manufaktur-dinilai-masih-ekspansif.

[16] Japlani, A. (2015). Apakah ukuran itu penting? (Studi empiris pada perusahaan manufaktur di Bursa Efek Jakarta tahun 2012-2014). Jurnal Akuisisi, 11(1), 1-21.

[17] Kusnadi, Y., \& Wei, K. C. J. (2012). The effects of political connections on the level and value of cash holdings: International evidence. Research Collection School of Accountancy, 1-44. Retrieved from https://ink.library.smu.edu.sg/soa_research/1 133.

[18] Kusumawati, D. U. (May 29, 2015). Utang Lapindo ke pemerintah Jokowi harus lunas dalam 4 tahun. Retrieved from https://www.cnnindonesia.com/nasional/201 50529103307-20-56458/utang-lapindo-kepemerintah-jokowi-harus-lunas-dalam-4tahun.

[19] Song, Z., Abraham, N., \& Yang, J. (2016). Institutional environment, political connection of partial state ownership, and performance, International Journal of Social Economics, 43(8), 856-870. Doi: 10.1108/IJSE-10-2014-0210. 
[20] Sugeng, B. (2017). Manajemen keuangan fundamental. Yogyakarta: Deepublish.

[21] Wulandari, L. (2018). Pengaruh political connection pada dewan komisaris dan dewan direksi terhadap kinerja perusahaan sector pertambangan yang terdaftar di Bursa Efek Indonesia (BEI) periode tahun 2010-2014. Jurnal Ilmiah Mahasiswa Universitas Surabaya, 7(1), 1-31. Retrieved from file://C:/Users/AIBPM/Downloads/1249-12169-1-10-20180720.pdf.
[22] Wulandari, T. \& Raharja, R. (2013). Analysis pengaruh political connection dan struktur kepemilikan terhadap kinerja perusahaan. Diponegoro Journal of Accounting, 2(1), 141-152. Retrieved from https://ejournal3.undip.ac.id/index.php/acco unting/article/view/2290/2309. 